\title{
The Impact of Working from Home Induced by Covid 19 On Working Women in Harare, Zimbabwe
}

\section{Orippah Gatsi, Anjali Devi and Rohini Devi}

To Link this Article: http://dx.doi.org/10.6007/IJARBSS/v11-i10/11275

DOI:10.6007/IJARBSS/v11-i10/11275

Received: 07 August 2021, Revised: 25 August 2021, Accepted: 10 September 2021

Published Online: 02 October 2021

In-Text Citation: (Gatsi et al., 2021)

To Cite this Article: Gatsi, O., Devi, A., \& Devi, R. (2021). The Impact of Working from Home Induced by Covid 19 On Working Women in Harare, Zimbabwe. International Journal of Academic Research in Business and Social Sciences, 11(10), 52-57.

Copyright: (c) 2021 The Author(s)

Published by Human Resource Management Academic Research Society (www.hrmars.com)

This article is published under the Creative Commons Attribution (CC BY 4.0) license. Anyone may reproduce, distribute, translate and create derivative works of this article (for both commercial and non-commercial purposes), subject to full attribution to the original publication and authors. The full terms of this license may be seen at: http://creativecommons.org/licences/by/4.0/legalcode

Vol. 11, No. 10, 2021, Pg. 52 - 57

Full Terms \& Conditions of access and use can be found at http://hrmars.com/index.php/pages/detail/publication-ethics 


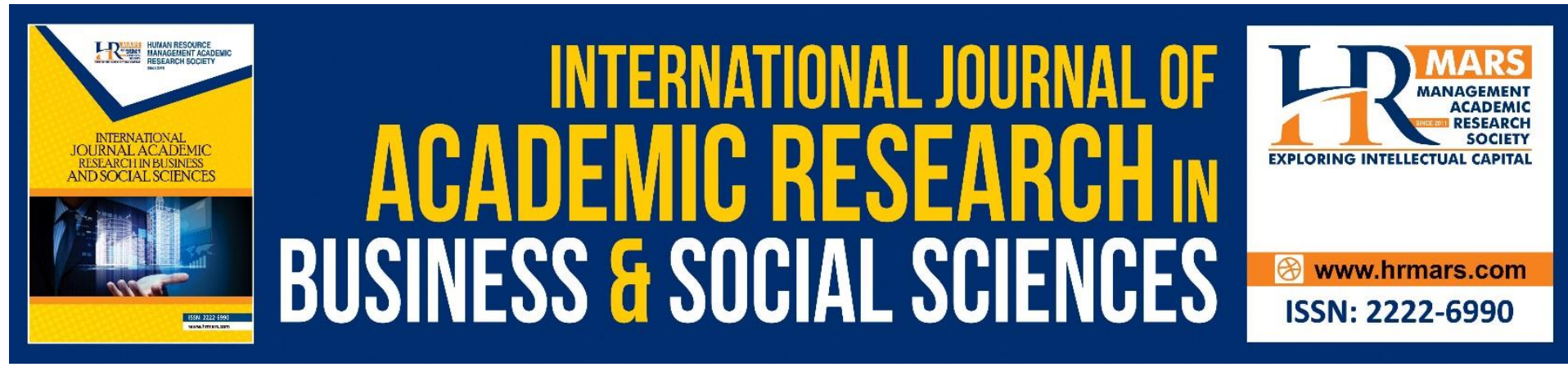

\title{
The Impact of Working from Home Induced by Covid 19 On Working Women in Harare, Zimbabwe
}

\section{${ }^{1}$ Orippah Gatsi, ${ }^{2}$ Anjali Devi and ${ }^{3}$ Dr Rohini Devi}

${ }^{1} \mathrm{PhD}$ Researcher, Binary University of Management \& Entrepreneurship, Malaysia, ${ }^{2}$ Senior Lecturer, Binary University of Management \& Entrepreneurship, Malaysia and ${ }^{3}$ Professor and Deputy Vice Chancellor, Binary University of Management \& Entrepreneurship,

Malaysia

\begin{abstract}
Working from home (WFH) can be a challenge as well especially in third world countries due to economic constrains as some people cannot afford gadgets and internet. Women are not spared as well as they are involved in multi-task. Drawing from employee isolation literature, this paper aimed to examine the impact of working from home on female employees during the imposed lockdown. Qualitative research was employed and in-depth interviews with 25 working women from different professions were conducted to gather data. Purposive and convenient sampling was used to select 25 working women from different professions and data was analyzed using MAXQDA software. The research finds out that, women are working overtime due their gender roles as caregiver and the fact that they are mothers, daughters, aunt, sisters, and daughter in-laws they end up involving in multi-task since they are at home, they find it is difficult to convince people that they are working since they will be at home and they cannot ignore visitors during working hours since women are known for their hospitality role in the family hence resulting in mental exhaustion. The study recommended more studies to be carried out on the impact of working from home to assist policy makers on the way forward during Covid 19 era.
\end{abstract}

Keywords: Working from Home, Covid 19, Working Women, Zimbabwe

\section{Introduction}

The Covid pandemic has brought in new normalcy to the globe overnight, due to the rapid spread of the virus schools had to close hence no-more boarding or day schooling. This new normalcy has led to children spend more time at home hence parents are taking care of their own children. Nations had to impose lockdown, and social distancing became the new norm where most people are forced to work from home, only essential workers like defense force and healthcare officials, food industry like grocery outlets workforce have been pushed to work outside their homes. Lockdown has caused untold suffering to self-employed individuals or street vendors because they cannot run their business as usual and Gross National Product of many nations is affected due to reduction in exports and imports. Although working from home has many benefits in reducing the spread of the virus since employees will be safe from 
getting infected, they can practice social distancing with ease, and are comfortable while working from the comfort of their homes. Working from home mantra is cost effective since there is no transport fare involved, and families tend to spend more time together. However, working from home can be a challenge as well especially in third world countries due to economic constrains, some people cannot afford gadgets and internet. Women are not spared as well as they are involved in multi-task. A recent study by Feng and Savani (2020) indicated that women's productivity was more disrupted than their male counterparts and they felt dissatisfied with their job. Drawing from employee isolation literature, this paper aimed to examine the impact of working from home on female employees during the imposed lockdown.

\section{Background}

WFH, is currently serving as an alternative working to reduce the spread of COVID-19 infection. WFH phenomenon was initially highlighted by Nilles (1988), the concept was referred to as "telecommuting" or "telework". WFH has been defined in various terms over the four decades, namely remote work, flexible workplace, telework, telecommuting, eworking. It is also referred to as virtual working. All these terms refer to the ability of employees to work remotely, especially at home, by using technology to execute work duties (Gajendran and Harrison, 2007: Grant et al, 2019). Gajendran and Harrison (2007) and Al Qalhati et al. (2020) described telecommuting as "an alternative work arrangement in which employees perform tasks elsewhere that are normally done in primary or central workplaces, for at least some portion of their work schedule, using electronic media to interact with others inside and outside the organization.

Women are known to be caregivers due to their gender roles. In most societies' women are employed as housemaids due to their socially constructed roles as caregivers. Historically, nature of their jobs makes them invisible in development because they were and still involved in development whilst in private domain hence when it comes to researches on how many women and men were contributing to development women were nowhere to be found because researches were carried out in public domain hence women were left out. Boserup (1970) noted that women were contributing to development especially in African agrarian economies, yet they were invisible. This led to the emergence of Women in Development (WID), Women and Development (WAD) and Gender and Development (GAD) so that women can be visible in development. The first approach was WID which focused on inclusion of women in development, their major concern was quantity of women in development not quality. Then WAD came as a reaction and addition to the already existing approach WID, WAD was worried about the quality of women in development not quantity, they needed women with a voice to be involved in development so that they can make a difference. GAD then come as a reaction to WID and WAD because WID and WAD were concentrating on women alone hence men were left behind thereby creating another power imbalance between men and women instead of equality. The purpose of GAD is to bridge the gap between men and women so that there will be at par in terms of access to equal opportunities in the society. However, Covid pandemic seems to reverse all the positives of WID, WAD and GAD due to the imposed lockdown whereby people are forced to work from home hence overburdening women with more duties. 
Zimbabwe recorded its first case 20 March 2020 (The Herald, 2020) and the nation was plunged into a panic mode as the nation recorded its first death from Covid the same month. Zimbabwe like any other country facing this devastating infection had to adopt different means to reduce the spread of virus, these include social distancing, masking up, sanitizing and hands washing prescribed by World Health Organization (WHO). The decision to suspend physical meetings and working was implemented swiftly without any guidance on how to do so. Decisions were made whilst people were in panicking mode hence all other shortfalls of WFH like limited resources especially access to internet and electrical power load shed and access to proper working space whilst at home, gadgets and proper training were not considered.

Most people in Zimbabwe live in shared homes whereby an individual or a family can rent one room or so whilst others occupy the other rooms hence working space can be a challenge. With the economic situation in Zimbabwe most households do no have access to internet let alone gadgets like smart phone and laptops.

\section{Objective and scope of the Study}

This paper focuses on the experiences of employed women who are working from home due to imposed lockdown. It focuses on women in Harare, Zimbabwe despite their profession.

\section{Literature Review}

Some studies uncovered that WFH had negative effects on the domain of life. Grant et al (2019) uncovered that e-workers find it difficult to manage boundaries between working and non-working time resulting in a tendency to overwork. Others uncovered that there were blurred boundaries between work and family life (Grant et al 2013) and may lead to overwork and in turn reduce WLB. Nevertheless, several studies found that WFH is positively associated with family and life satisfaction (Eddleston and Mulki 2017; Virick, DaSilva, and Arrington 2010). Baruch (2000) suggested some factors that need to be addressed for teleworking to be successful, such as "self-discipline, self-motivation, ability to work independently, tenacity, self-organization, self-confidence, time management skills, computer literacy knowledge. A study carried out by Blom et al. (2017) revealed inequality between men and women created by WFH. The study reviewed that WFH has favorable outcome among men than women as it facilitates management of household responsibilities while maintaining professional employment. Women more often are constrained in their use of technology. Balancing working hours and household responsibilities is a concern for women. On job satisfaction women indicated that they were not satisfied working from home (Gash et al, 2012; Al Qalhati et al., 2020; Javed et al., 2020).

Covid pandemic does not only affects medical and economic facets but psychological aspect as well. Findings from research done by imply that the COVID-19 pandemic represents not only a major medical and economic crisis, but also has a psychological dimension, as it can be associated with declines in key facets of people's subjective wellbeing. They recommended that psychological practitioners need to address potential declines in subjective wellbeing with their clients and attempt to enhance clients' general capability to use functional stress appraisals and effective coping strategies.

\section{Methodology}

Qualitative research was employed and in-depth interviews with 25 working women from different professions were conducted to gather data. Purposive and convenient sampling 
were used to select 25 working women from different professions and data was analyzed using MAXQDA software.

\section{Research Findings}

Although some women indicated that they were satisfied working from because it gives them ample time to spend with their family. They indicated that they are now able to monitor the progress of their children unlike during the era of physical office where they had to live their children in the hands of their house helpers, for them virtual office is drawing them closer to their children. However, negatives outweigh positives as women highlighted that they are failing to demarcate between office time and family time hence difficult to manage time which is causing them to work overnight trying to finish their office work and household chores. Women indicated that they are psychologically and physically drained by the time they go to bed. Most women indicated that they had to send their house helpers away so that they too can practice social distancing rather than travelling from their home to work every day and this has worsened their situation because they are now performing the duties which were previously performed by their house helpers. This new way of living has exerted too much pressure on working women as they indicated that they are now involved in dual roles as housekeepers and office workers, a situation they described as challenging.

Most women indicated that they get less salaries as compared to their husbands hence they give preference to their husbands when it comes to working space sharing. Another respondent highlighted said that they only have 2 rooms hence sharing working space with her husband and 2 children is a nightmare. She said sometimes she would lock herself inside the bathroom so that she can find a quiet place she said she hates virtual meetings due to lack of working space.

Women indicated that apart from office work and housework they must assist their children with their homework as well. Although some women were delighted to get the opportunity to monitor their children's progress, they said its hectic considering the duties they must accomplish in a day. Most women indicated that they are missing their working place because they are certain duties they enjoy working as a team hence working virtually has affected them psychologically.

\section{Conclusion}

It is crystal clear from the findings of this research that WFH has proven not to be the best option for the majority of working women because women are working overtime due their gender roles as caregiver and the fact that they are mothers, daughters, aunt, sisters, and daughter in-laws they end up involving in multi-task since they are at home, they find it is difficult to convince people that they are working since they will be at home and they cannot ignore visitors during working hours since women are known for their hospitality role in the family hence resulting in mental exhaustion.

\section{Recommendations}

The below recommendations include a series of possible actions that could be taken by the Government and employers to make women WFH feel comfortable.

- The study recommended more studies to be carried out on the impact of working from home to assist policy makers on the way forward during covid 19 era.

- Feasible gender guidelines and policies from the government should be in place to properly regulate and make WFH feasible. 
- Men should be encouraged to assist women with domestic chores

- To further promote family-friendly employment practices for men and women.

\section{References}

Al Qalhati, N., Karim, A. M., Al Mughairi, B., Al Hilali, K., \& Hossain, M. I. (2020). Technology and HR Practices in Educational Sector in Sharqiya Governate of Oman. International Journal of Academic Research in Business and Social Sciences. 10(10), 435-443.

Al Qalhati, N., Karim, A. M., Al Mughairi, B., Al Hilali, K., \& Hossain, M. I. (2020). Study on Job Satisfaction among Teachers in Sultanate of Oman. International Journal of Academic Research in Business and Social Sciences. 10(10), 422-434.

Blom, N., Kraaykamp, G., \& Verbakel, E. (2017). Couples' division of employment and household chores and relationship satisfaction: a test of the specialization and equity hypotheses, European Sociological Review 33(2): 195-208.

Boserup E, (1970). Women's Role in Economic Development, The University of Chicago Press.

Czymara, C. S., Langenkamp, A., \& Cano, T. (2020). Cause for concerns: gender inequality in experiencing the COVID-19 lockdown in Germany, European Societies, 1-14.

Felstead, A., \& Henseke, G. (2017). Assessing the growth of remote working and its consequences for effort, well-being and work-life balance', New Technology, Work and Employment 32(3): 195-212. doi:10.1111/ntwe.12097.

Feng, Z., \& Savani, K. (2020). Covid-19 created a gender gap in perceived work productivity and job satisfaction: implications for dual-career parents working from home, Gender in Management, Vol. 35 No. 7/8, pp. 719-736. https://doi.org/10.1108/GM-07-20200202

Gash, V., Mertens, A., \& Gordo, L. R. (2012). The influence of changing hours of work on women's life satisfaction, The Manchester School 80(1): 51-74.

Javed, M., Hock, O. Y., \& Asif, M. K., Hossain, M. I. (2020). Assessing the Impact of Emotional Intelligence on Job Satisfaction among Private School Teachers of Hyderabad, India. International Journal of Psychosocial Rehabilitation. 24(4). 5035-5045

Lejeune, O. (2020) Coronavirus counter-measures tracker. Retrieved from: https://coronavirusmeasures.herokuapp.com/.

Nilles, J. M. (1988). Traffic reduction by telecommuting: A status review and selected bibliography, Elsevier Ltd

Song, Y., \& Gao, J. (2019) 'Does telework stress employees out? A study on working at home and subjective well-being for wage/salary workers', Journal of Happiness Studies 76: 121.

The Herald. (2020). https://www.herald.co.zw/zimbabwe-confirms-first-covid-19-case/ [Online]

Wheatley, D. (2017). Employee satisfaction and use of flexible working arrangements', Work, Employment and Society 31(4): 567-85.

World Health Organisation. (2020). COVID-19 Public Health Emergency of International Concern (PHEIC) Global Research and Innovation Forum." Accessed 12 Feb 2020. https://www.who.int/publications/m/item/covid-19-public-health-emergencyof-international-concern-(pheic)-global-research-and-innovation-forum

World Health Organization. (2020). Coronavirus Disease (COVID-19) Situation Report - 202. Accessed 9 August 2020. https://www.who.int/docs/defaultsource/coronaviruse/situation-reports/2,02,00,809-covid-19-sitrep202.pdf?sfvrsn=2c7459f6_2 